\begin{tabular}{|c|l|}
\hline Title & Changes in carbon stock foll owing soil scarification of non-wooded stands in Hokkaido, northern Japan \\
\hline Author(s) & A oyama, Keiichi; Y oshida, Toshiya; Harada, A kane; Noguchi, Mahoko; Miya, Hisashi; Shibata, Hideaki \\
\hline Citation & $\begin{array}{l}\text { Journal of Forest Research, 16(1), 35-45 } \\
\text { https://doi.org/40.1007/310310-010-0204-y }\end{array}$ \\
\hline Issue Date & 2011-02 \\
\hline Doc URL & http://hdl.handle.net/2115/44956 \\
\hline Rights & The original publication is available at www.springerlink.com \\
\hline Type & article (author version) \\
\hline File Information & JFR16-1_35-45.pdf \\
\hline
\end{tabular}

Instructions for use 


\section{Changes in carbon stock following soil scarification of non-wooded stands in Hokkaido, northern Japan}

Keiichi Aoyama; Graduate School of Environmental Science, Hokkaido University (keiichiaoyama@hotmail.com)

Toshiya Yoshida ${ }^{1}$; Uryu Experimental Forest, Field Science Center for Northern Biosphere, Hokkaido University (yoto@fsc.hokudai.ac.jp)

Akane Harada; Graduate School of Environmental Science, Hokkaido University (a.harada.2-147@hotmail.co.jp)

Mahoko Noguchi; Shikoku Research Center, Forestry and Forest Products Research Institute (mahoko@affrc.go.jp)

Hisashi Miya; Graduate School of Agriculture, Hokkaido University (miya@for.agr.hokudai.ac.jp)

Hideaki Shibata Northern Forestry and Development Office, Field Science Center for Northern Biosphere, Hokkaido University (shiba@fsc.hokudai.ac.jp)

${ }^{1}$ Corresponding author

Moshiri 074-0741, Horokanai, Hokkaido, JAPAN

Tel: +81-165-38-2125; Fax: +81-165-38-2410

E-mail: yoto@fsc.hokudai.ac.jp 
Aoyama et al., 2

\begin{abstract}
To restore nonwooded stands dominated by dwarf bamboo species (Sasa kurilensis or S. senanensis) into forests, mechanical soil scarification has been applied in northern Japan since the 1960s. The treatment is followed both by natural regeneration and artificial planting. In this study, we quantified the total carbon stock (plants plus $0.3 \mathrm{~m}$ depth of soil) of these stands over 35-year age-sequences. The natural regeneration stands were gradually dominated by Betula ermanii. The carbon stock increased linearly to $215.1 \pm 35.2 \mathrm{Mg} \mathrm{C} \mathrm{ha}^{-1}$ for 37-year-old stand formerly dominated by $\mathrm{S}$. kurilensis, and 181.1 $\pm 29.8 \mathrm{Mg} \mathrm{C} \mathrm{ha}^{-1}$ for 34-year-old stand formerly dominated by S. senanensis. The latter was similar to that of a Picea glehnii plantation, formerly dominated by S. senanensis, with comparable stand age $\left(160.3 \pm 6.7 \mathrm{Mg} \mathrm{C} \mathrm{ha}^{-1}\right.$ for 35-year-old stands). Although the carbon stock in plants quickly offset the untreated level, that in the soil remained depressed even in the older stands. This resulted in small differences in carbon stock of these stands with untreated dwarf bamboo stands. We conclude that natural regeneration following scarification could be a prime option for carbon sink management in the region. However, we should take a long rotation period (i.e. > 50-year) to ensure a carbon sink state. A potential of further improvements of the practice, including that reduce intensity of soil disturbance, was presented.
\end{abstract}

Keywords cool-temperate forest; afforestation; dwarf bamboo; natural regeneration; carbon sink management 
Aoyama et al., 3

\section{Introduction}

Human-induced land-use changes are a significant factor for ecosystem carbon cycling (Houghton et al. 1999; Caspersen et al. 2000; Potter et al. 2006). In the Kyoto Protocol, afforestation and reforestation, both of which aimed to restore forests, are assumed to the management activities leading to a stand becoming a net long-term carbon sink. Consequently, the role of forest management in ecosystem carbon cycling is increasingly of concern, and accurate predictions of the effects of management practices on the carbon budget are required (IGBP Terrestrial Carbon Working Group 1998). However, regimes of forestry management appropriate for the sink activity are still under examination (Johnson and Curtis 2001; Jandl et al. 2007) for many regions.

We regard that natural regeneration or planting following site preparation could be an effective sink activity. As natural regeneration could substantially reduce management costs, to quantify its effect on carbon stock is significant for policy makers. The age-sequential carbon accumulations after a major disturbance have been described in many types of forest stands (e.g. Wirth et al. 2002; Hooker and Compton 2003; Rothstein et al. 2004; Peichl and Arain 2006). Nevertheless, empirical data comparing the carbon stock in naturally regenerated stands directly with that in plantations in the same region are scant.

In Hokkaido, the northernmost island of Japan, there are estimated to be more than one million hectares of nonwooded forestlands (Hokkaido Pref. 2009), which are mostly dominated by dwarf bamboo species (Sasa kurilensis (Rupr.) Makino \& Shibata and S. senanensis (Franch. \& Savat.) Rehd.). Although these dwarf bamboo stands often occur as natural vegetation, especially in snowy, high altitude areas, their distribution seems to widen with deforestation. Since the early $20^{\text {th }}$ century, deforestation was caused not only by natural disturbances (e.g. severe wind throw) but also by human disturbances such as logging and artificial fire (Noguchi and Yoshida 2005). Once dense thickets of dwarf bamboo develop, natural regeneration of trees generally fails, because dwarf bamboos inhibit establishment and growth of tree seedlings (Noguchi and Yoshida 2004). 
To restore these nonwooded stands into forests, mechanical site preparation (soil scarification) has been used since the 1960s in Hokkaido. Scarification is surface soil displacement with civil engineering machinery, such as a bulldozer, to improve the substrate by removing understory competitors (i.e. dwarf bamboos) for tree regeneration. In most cases, the treatment facilitates the establishment of secondary stands dominated by birch, Betula spp. (B. ermanii Cham. and B. platyphylla Sukatcher var. japonica (Miq.) Hara.) (Umeki 2003; Yoshida et al. 2005).

Such a successful natural regeneration following mechanical site preparation has been widely reported in cool-temperate and boreal forests (Wurtz and Zasada 2001; Nilsson et al. 2002; Zaczek 2002; Haeussler 2004; Gastaldello et al. 2007). We expect that the scarified stand would become a carbon sink as trees grow. However, the total effect of the management is uncertain because the practice strongly disturbs the soil layer that could be a principal carbon sink in a forest (Dixon et al. 1994; Schimel 1995). The removal of surface soil, which is likely to reduce net primary production of plants and enhance decomposition of litter and organic matter, would result in carbon losses following the treatment (cf. Zak et al. 1990; Richter et al. 1999; Dawson and Smith 2007; Jandl et al. 2007), potentially leading to the stand becoming a net carbon source to the atmosphere. We need an evaluation of the potential of scarification treatment for utilizing it as a regional carbon sink management.

The objective of this study was to estimate the carbon stock in plants, litter and soil at naturally regenerated stands in 35-year age-sequences, which included the oldest treatment stands in Hokkaido. The carbon stocks quantified were then compared with those of plantations of spruce, Picea glehnii Masters, which are also a major landscape component in the region, to determine the relative effectiveness of natural versus planted regeneration. We predicted that natural regeneration stands would show a comparable level of recovery of biomass carbon to plantations because of the rapid growth of regenerating birch (Umeki 2003). Comparisons were also made with untreated dwarf bamboo stands, with an unexamined assumption that these stands represent the pre-treatment 
condition, to roughly estimate the state (sink or source) of the stands. We predicted that carbon stock in the age-sequence would be lower than untreated stands in the first few decades and be similar or greater in the older stage. We examined two types of naturally regenerated stands that differed in dominating dwarf bamboo species along with the altitude (S. kurilensis is distributed in higher areas than $S$. senanensis). We predicted that the naturally regenerated stands, formerly dominated by $S$. senanensis, would have higher carbon accumulation because of suitable climatic conditions for tree regeneration. Based on the results, we presented some management implications that may contribute to carbon sink management in forests in the region.

\section{Materials and methods}

\section{Study stands}

The study was conducted in the Uryu Experimental Forest, Hokkaido University, located on Hokkaido Island in northern Japan $\left(24,000\right.$ ha; $\left.44^{\circ} 24^{\prime} \mathrm{N}, 142^{\circ} 07^{\prime} \mathrm{E}\right)$. The mean annual air temperature is $4.2^{\circ} \mathrm{C}$, and the mean annual precipitation is $1236 \mathrm{~mm}$ (from 1997 to 2006; Uryu Experimental Forest, unpublished). Snow cover usually extends from late November to early May, with a maximum depth of about $3 \mathrm{~m}$. The predominant soil is an Inceptisol (acidic brown forest soil), and the predominant bedrock is Tertiary andesite (Uryu Experimental Forest, unpublished).

We investigated regeneration stands with stand ages up to about 35 years, the oldest age of naturally regenerated stand in the region, for this study. Before the treatments, Sasa kurilensis or $S$. senanensis had exclusively dominated these stands. Sasa kurilensis predominates at higher altitudes (> $400 \mathrm{~m}$ ), forming large monospecific communities, while $S$. senanensis is mainly distributed at lower altitudes, showing dense cover in nonwooded openings in natural conifer-broadleaved mixed forests. Despite the differences in climatic conditions and the surrounding vegetation, both these types of naturally regenerated stands recovered with birch, B. ermanii, at a later stage. Although we found B. platyphylla var. japonica, especially at lower altitudes, all our study stands consisted 
mainly of B. ermanii.

We examined six naturally regenerated stands formerly dominated by S. kurilensis (2-37 years after the treatment; NRsk) or S. senanensis (1-34 years after the treatment; NRss) (Table 1). All the stands are located in the flat area, with similar soil and bedrock conditions. The forest floor was scarified with a bulldozer with an attachment that raked the soil to a depth of about $0.1 \mathrm{~m}$. Most of the understory vegetation and surface soil was pushed off the scarified area.

For comparison, we selected six P. glehnii plantations from the area. As plantations at high altitudes are uncommon, all these stands were located in the area formerly dominated by $S$. senanensis (3-35 years after planting; PLss). The original choice of the management regime (i.e., natural regeneration or planting) was decided upon mainly for logistical reasons (e.g., distance from the forest road), and we could set these plantation stands neighbor to the NRss stands, ensuring comparable climatic and topographic conditions. After the surface soil removal with a bulldozer, similar to the scarification treatment, seedlings of 3-4-year-old P. glehnii were planted with an initial density of $2000-2500 \mathrm{ha}^{-1}$. After planting, these stands were weeded once a year (this eliminated competitive plants from the seedlings) during the initial 6-7 years followed by a thinning treatment when they were about 20 years old.

In addition, we examined three untreated stands respectively for $S$. kurilensis (UTsk) and $S$. senanensis (UTss). In this study, we assumed these stands were representative of the pre-treatment condition (i.e. there was no change in carbon stocks over the period considered), although very little is known about the dynamics of dwarf bamboos stands in a long term. Previous reports suggested that $S$. kurilensis had more mean above ground biomass than $S$. senanensis due to its taller and thicker culms (Kawahara and Suzuki, 1981). We selected stands where the two dwarf bamboo species did not coexist, and where non-wooded condition has been maintained at least during 35 years (checked with aerial photographs).

Furthermore, we examined an improved scarification treatment, in which normal practice was 
followed by replacing the scarified soil. In that treatment, soils that were removed and piled in mounds was replaced on the scarification area with a bulldozer. We expected rapid vegetation recovery due to the nutrient rich nature of the replaced soil (Aoyama et al. 2009). As this treatment is in the trial stage, we could examine only two younger stands that were set up in the $S$. senanensis predominant area (one and seven years after the soil-replacement; INRss).

\section{Methods}

We investigated the carbon stock in four basic components of a forest; overstory trees (including standing dead trees), understory vegetation, plant litter (including leaf litter, twigs and humus layer and downed woody debris), and $0.3 \mathrm{~m}$ depth of mineral soil. In each stand, we set three study plots, which were at least $20 \mathrm{~m}$ apart from the stand edge and each plot was at least $20 \mathrm{~m}$ from another plot. The carbon stock in each of the four components was estimated according to the following procedures.

\section{Overstory trees and standing dead trees}

In this study, we regarded trees with height equal to or taller than $120 \mathrm{~cm}$ as 'overstory trees'. We measured the diameter at breast height $(\mathrm{DBH} ; \mathrm{cm})$ and height $(\mathrm{H} ; \mathrm{cm})$ of all the overstory trees (including standing dead trees) in the circular plot. The sizes of the circular plots were $200 \mathrm{~m}^{2}, 100$ $\mathrm{m}^{2}$ and $50 \mathrm{~m}^{2}$, for trees with DBH equal to or larger than $10 \mathrm{~cm}$, DBH equal to or larger than $5 \mathrm{~cm}$ (and smaller than $10 \mathrm{~cm}$ ) and DBH smaller than $5 \mathrm{~cm}$, respectively.

We estimated dry mass (trunk, branch, leaf, and coarse root) using previously established allometric equations (Table 2). For all broadleaved species, the equations for B. ermanii, which was a predominant species in naturally regenerated stands (Fig. 1), were applied. For all conifers, the allometric equations for P. glehnii, the planted species, were used. The standing dead trees were assumed to have the half dry mass (we did not have a data on this component, and we tentatively used this assumption as a possible value), estimated from the same allometric equations without those for leaves. The carbon stock was calculated, assuming that the carbon concentration is $50 \%$ of 
the dry mass (Coomes et al 2002). Then we used the average of the estimated dry mass of the three plots as a representative of each stand.

\section{Understory plants}

The aboveground part of the understory vegetation was clipped in a $1 \mathrm{~m}^{2}$ quadrat at each study plot. We divided the samples into dwarf bamboos, tall forbs, tree saplings and others, and their dry mass were measured. The subsamples were dissolved by KCL (1:5) and determined the carbon concentration by using the CHNS/O analyzer (Perkin Elmer Japan, Yokohama, Japan). (Table 3). The carbon stocks were estimated by multiplying the dry mass by the concentration, and the average of the three plots was used as a representative for each stand.

We examined the belowground (roots and rhizomes), to a depth of $0.3 \mathrm{~m}$, of the understory vegetation. It has been documented that nearly $90 \%$ of the root systems of dwarf bamboos were concentrated in this depth (Fukuzawa et al., 2007). For a depth of 0-0.1 m, where root systems are densest, we picked out samples by hands from a nested $0.25 \mathrm{~m}^{2}$ quadrat that were set up in the $1 \mathrm{~m}^{2}$ quadrat. In addition, we collected three $100 \mathrm{~cm}^{3}$ soil cores respectively from depths of $0.1-0.2$ and 0.2-0.3 m. All the fine roots in the samples were separated from the soil. Because coarse roots of overstory trees were estimated by the allometric equations (see above), these quadrats were located a few meters away from overstory trees to minimize the double counting; the identifiable overstory tree's coarse roots were removed from the samples. We note that the samples contained dead roots that were hard to distinguish. The dry masses and the carbon concentrations (Table 3) were measured, and their products were used as carbon stocks.

\section{Plant litter and downed woody debris}

We sampled plant leaf litter, fallen twigs and branches (diameter $5 \mathrm{~cm}$ or smaller) and humus layer from the nested $0.25 \mathrm{~m}^{2}$ quadrat that were set up in the $1 \mathrm{~m}^{2}$ quadrat. We dried all these samples and measured their dry masses. The carbon concentrations were determined (Table 3), and their products with the dry masses were used as carbon stocks. 
We accounted for the amount of downed coarse woody debris in the three $100 \mathrm{~m}^{2}$ circular plots for each stand. We estimated the volume by measuring the total length and diameter at each end of all woody debris, $5 \mathrm{~cm}$ in diameter or greater. Each piece of the coarse woody debris was classified into three decay classes: 1. Bark intact; 2. Bark and twigs lost, but wood sound; 3. Shape maintained, but wood yielding to pressure. For decay class 1 , the published values of the specific gravity of woods ( $\mathrm{kg} \mathrm{m}^{-3}$; Wood Technology and Wood Utilization Division, 1982) were applied to estimate the dry mass; the values for B. ermanii $\left(560 \mathrm{~kg} \mathrm{~m}^{-3}\right)$ and P. glehnii $\left(369 \mathrm{~kg} / \mathrm{m}^{-3}\right)$ represented broadleaved and conifer species respectively. For decay class 2 and 3, the wood densities (dry mass / wood volume) were measured using the samples. Then we quantified carbon stock with the estimated dry mass and carbon concentrations (assumed to be 50\% of the dry mass; Laiho and Prescott 1999).

\section{Soil}

We collected soil samples with $100 \mathrm{~cm}^{3}$ soil cores from the quadrat for each study plot at depths of $0-0.1,0.1-0.2$, and $0.2-0.3 \mathrm{~m}$. The effects of coarse fragments (roots or stones) on the volume were negligible. Although the carbon stock in the deeper soil might be required for estimating the total ecosystem carbon accumulation, we examined the surface $0.3 \mathrm{~m}$ because our primary objective was to evaluate the effects of the treatments. In the laboratory, the dry masses and the carbon concentrations (Table 3) were measured, and their products were used as carbon stocks.

\section{Soil mounds}

In the regenerated stands, scarified soil were piled in mounds around the stands, and remained untouched. For the total evaluation, we examined carbon stock in these mounds. We randomly selected a mound and set up a quadrat (equal to or larger than $20 \mathrm{~m}^{2}$ ) for each stand. The estimation of carbon stock in a mound was done as below, similar to that described above. We measured DBH and height of all overstory trees (height equal to or larger than $1.2 \mathrm{~m}$, including standing dead trees) and volume of the coarse woody debris (diameter equal to or larger than $5 \mathrm{~cm}$ ) in the whole plot. In addition, we sampled understory plants (including roots and rhizomes), litter, fallen twigs (diameter 
$5 \mathrm{~cm}$ or smaller) and soils in a $1 \mathrm{~m}^{2}$ quadrat. The soil depth examined was $0.6 \mathrm{~m}$, which was the average height of the mounds. We collected two soil samples respectively from depths of 0-0.3 and $0.3-0.6 \mathrm{~m}$.

Based on actual measurement at the two-year-old S. senanensis scarified stand, we found that the scarification treatment removed surface soil to $0.1 \mathrm{~m}$ depth (also see Yoshida et al., 2005), and the piling process (to make mounds) reduced the volume of scarified soil to about $60 \%$ by machinery compaction. With considering the usual mound shape (semi cylindrical shape with $0.6 \mathrm{~m}$ height), we could assume that the scarified soil $\left(600 \mathrm{~m}^{3} \mathrm{ha}^{-1} ; 100 \mathrm{~m} \times 100 \mathrm{~m} \times 0.1 \mathrm{~m} \times 0.6\right)$ add $1274 \mathrm{~m}^{2}$ of the mound area to a hector of scarified area (i.e. mound are share $11.3 \%$ of the total treated area). The estimated carbon stock for the scarified area and the mound were integrated with this percent area.

\section{Analyses}

The statistical analyses were based on the average of the three plots at each stand. The Mann-Whitney U test was applied to examine the differences in average among stands. The changes in carbon stock in the age-sequences were evaluated with the linear regression. Because we examined only younger developmental stage, the asymptotic curves were not considered for the changes.

\section{Results}

\section{Vegetation development}

In the initial 10 years, vegetation in the naturally regenerated stands was mostly composed of tall forbs (such as Reynoutria sachalinensis (Fr. Schm.) Nakai and Cirsium kamtschaticum Ledeb.) (Fig. 1). Tall forbs established mostly on mounds (accumulation of the scarified soil), and rarely occurred in scarified areas where most of the surface soil was removed (data are not shown). After that, $B$. ermanii gradually increased and accounted for $80 \%$ of the total stem density at the oldest stands (Table 4). The tall tree species other than B. ermanii were more frequent in NRss (naturally 
regenerated stands formerly dominated by S. senanensis) than NRsk (those formerly dominated by $S$. kurilensis). In PLss (P. glehnii plantations formerly dominated by S. senanensis), the dominance of $P$. glehnii increased smoothly and accounted for more than $90 \%$ of the total density in the 30 -year-old stand. The DBH-class distribution of overstory trees of the naturally regenerated stands (NRsk and NRss) showed the mode at the 5-10 cm class even in the oldest stands (Table 4). In contrast, trees in the planted P. glehnii stands (PLss) had a mode in the largest class (DBH equal to or larger than 15 $\mathrm{cm}$ ). The soil replacement stand (INRss) after 7 years was characterized by a particularly high stem density of B. ermanii (9 stems/ $\left.\mathrm{m}^{2}\right)$.

\section{Carbon stock in aboveground of overstory trees}

The aboveground carbon stock in overstory trees (height equal to or larger than $1.2 \mathrm{~m}$, including standing dead trees) increased linearly after about 10 years following the treatments in NRsk, NRss and PLss (Fig. 2a). The linear regressions of the carbon stock with stand age were significant $(p<$ 0.05). Standing dead trees occurred when the stand was about 15 years old, but its proportion of the total overstory tree mass was less than 2\% (Fig. 1). The observed carbon stocks in the oldest stands in this study were respectively $63.1 \pm 11.2 \mathrm{Mg} \mathrm{C} \mathrm{ha}^{-1}$ for 37-year-old NRsk, $67.6 \pm 19.9 \mathrm{Mg} \mathrm{C}^{-1}$ for 34-year-old NRss, and $55.7 \pm 7.2 \mathrm{Mg} \mathrm{C} \mathrm{ha}^{-1}$ for 35-year-old PLss (Fig 2a). Although the mean carbon stock of NRss was generally higher than that of PLss, there was no statistical difference between them. The carbon stock in seven-year-old INRss was considerably higher than that in eight-year-old NRss $(p<0.05)$ and comparable with that of 16-year-old NRss.

\section{Carbon stock in aboveground of understory trees}

With natural regeneration (NRsk and NRss), aboveground understory carbon stock increased with stand age ( $p<0.05$; Fig. 2b), however there was no significant change in the understory with stand age in the plantation stands. The understory on the naturally regenerated stands was mostly composed of recovering dwarf bamboo in both the older NRsk and NRss stands (Fig. 1). At the untreated stands, the estimates were $27.4 \pm 8.9 \mathrm{Mg} \mathrm{C} \mathrm{ha}^{-1}$ for UTsk (S. kurilensis stand), and $9.8 \pm$ 
3.6 $\mathrm{Mg} \mathrm{C} \mathrm{ha}^{-1}$ for UTss (S. senanensis stand), with a significant difference between them $(p<0.05)$. This difference was also maintained after the treatments; the oldest NRsk had about four times as much aboveground carbon stock in the understory plants as the oldest NRss or PLss $(p<0.05)$. The estimates in the oldest stands were $11.7 \pm 7.2 \mathrm{Mg} \mathrm{C} \mathrm{ha}^{-1}$ for NRsk (37-year-old) and $2.9 \pm 0.9 \mathrm{Mg} \mathrm{C}$ $\mathrm{ha}^{-1}$ for NRss (34-year-old) and they were significantly less than that in untreated stands $(p<0.05)$. The carbon stock of understory plants in PLss $\left(1.0 \pm 0.7 \mathrm{Mg} \mathrm{C} \mathrm{ha}^{-1}\right.$ in the 35-year-old stand) did not relate to stand age $(p>0.05)$. This stock was significantly less than that in UTss $(p<0.05)$.

\section{Carbon stock in belowground of plants}

The belowground plant carbon stocks (sum of the estimates of overstory trees and understory vegetation) also increased with stand age ( $p<0.05$; Fig. 2c), resulting in $29.1 \pm 3.3 \mathrm{Mg} \mathrm{C} \mathrm{ha}^{-1}$ in 37-year-old NRsk, $35.0 \pm 3.7 \mathrm{Mg} \mathrm{C}^{-1}$ in 34-year-old NRss and $24.6 \pm 1.0 \mathrm{Mg} \mathrm{C}^{-1}$ in 35-year-old PLss. These values were significantly higher than that of the corresponding untreated stand (11.4 $\pm 4.9 \mathrm{Mg} \mathrm{C} \mathrm{ha}^{-1}$ for UTsk and $12.7 \pm 3.9 \mathrm{Mg} \mathrm{C} \mathrm{ha}^{-1}$ for UTss $)(p<0.05)$. On average, the carbon stock in this component in the scarified stands exceeded that in untreated stands about 20 years after the treatment. The carbon stock in one-year-old INRss was almost the same as that in UTss (Fig 2c). Similarly, seven-year-old INRss showed a higher stock than eight-year-old NRss ( $p<$ $0.05)$.

\section{Carbon stock in total plants}

Total plant carbon stocks (the sum of aboveground and belowground carbon; Fig. 2d) increased linearly with stand age over 35 years in NRsk, NRss and PLss $(p<0.05)$, reflecting the trend observed in the aboveground part of the overstory trees. On average, the plant carbon stock of NRsk, NRss and PLss exceeded the corresponding untreated stands $\left(38.9 \pm 9.4 \mathrm{Mg} \mathrm{C} \mathrm{ha}^{-1}\right.$ in UTsk, and $22.6 \pm 4.4 \mathrm{Mg} \mathrm{C} \mathrm{ha}^{-1}$ in UTss) at about stand age 20. On the other hand, the plant carbon stock in seven-year-old INRss was already comparable with that in UTss.

\section{Carbon stocks in litter, downed woody debris and soil}


In NRss, carbon stock in the litter and downed woody debris related to stand age $(p<0.05$; Fig 2e). The relationship was not significant for NRsk and PLss, although it tended to be high in older stands (Fig. 2e). The estimates in the oldest stands were $10.8 \pm 1.4 \mathrm{Mg} \mathrm{C} \mathrm{ha}^{-1}$ for NRsk (37-year-old), $11.9 \pm 4.8 \mathrm{Mg} \mathrm{C}^{-1}$ for NRss (34-year-old), $6.4 \pm 2.5 \mathrm{Mg} \mathrm{C} \mathrm{ha}^{-1}$ for PLss (35-year-old), and they were not significantly different from the corresponding untreated stands $\left(10.2 \pm 3.0 \mathrm{Mg} \mathrm{Cha}^{-1}\right.$ in UTsk and $8.1 \pm 2.3 \mathrm{Mg} \mathrm{C} \mathrm{ha}^{-1}$ in UTss).

The carbon stock in the soil (0-0.3 m depth) in untreated stands (UTsk and UTss) was $142.7 \pm$ 33.8 $\mathrm{Mg} \mathrm{C} \mathrm{ha}{ }^{-1}$ and $108.2 \pm 18.5 \mathrm{Mg} \mathrm{C} \mathrm{ha}^{-1}$, respectively (Fig. 2f), with a statistically significant difference between them $(p<0.05)$. They decreased considerably (about two thirds) just after the treatment, and after that, they did not show clear trends with stand age. The estimates in the oldest stands were $100.4 \pm 12.3 \mathrm{Mg} \mathrm{C} \mathrm{ha}^{-1}$ in NRsk (37-year-old), $63.7 \pm 17.6 \mathrm{Mg} \mathrm{C}^{-1}$ in NRss (34-year-old) and $72.5 \pm 13.0 \mathrm{Mg} \mathrm{C} \mathrm{ha}^{-1}$ in PLss (35-year-old), and were significantly less than those in the corresponding untreated stands $(p<0.05)$.

\section{Total carbon stocks}

The total carbon stock (sum of all the components) in UTsk and UTss was $191.7 \pm 26.4 \mathrm{Mg} \mathrm{C} \mathrm{ha}^{-1}$ and $138.8 \pm 21.9 \mathrm{Mg} \mathrm{C} \mathrm{ha}^{-1}$, respectively, with a significant difference between them $(p<0.05)$. In the scarified stands (NRsk, NRss and PLss), total carbon stock increased linearly with stand age ( $p<$ 0.05; Fig. 2g) to $215.1 \pm 35.2 \mathrm{Mg} \mathrm{C} \mathrm{ha}^{-1}$ in the 37-year-old NRsk, $181.1 \pm 29.8 \mathrm{Mg} \mathrm{C} \mathrm{ha}^{-1}$ in the 34-year-old NRss, and $160.3 \pm 6.7 \mathrm{Mg} \mathrm{C} \mathrm{ha}^{-1}$ in the 35-year-old PLss. There was no significant difference between the oldest stands of NRss and PLss $(p>0.05)$. Soil was a major carbon sink in these stands (Fig 3). The share of plant components gradually increased with stand age, and reached nearly half of total carbon stock at the oldest stands examined. Although the carbon stock in the plants offset the untreated level about 20 years after the treatment (Fig. 2d), differences in total carbon stock between the scarified stands and the untreated stands were small; a significant difference was found only between NRss and UTss $(p<0.05)$. It appeared that the soil-replacement 
considerably raised the carbon stock, although we could only examine younger stages in this study. The total carbon stock in the seven-year-old INRss was comparable to the 26-year-old NRss ( $p>$ $0.05)$.

\section{Discussion}

The observed carbon stocks in the oldest scarified stands were comparable or higher than those reported in previous studies conducted in cool-temperate forests with similar stand age (30-50 year) (Hooker and Compton 2003; Rothstein et al. 2004; Jia and Akiyama 2005; Peichl and Arain 2006; Tremblay et al. 2006). We conclude that natural regeneration treatment could be a prime option for carbon sink activity in this region; our results revealed that natural regeneration by $B$. ermanii following soil scarification attained comparable total carbon stock with the P. glehnii plantations (Fig.2g). Although many larger trees were found in the plantations (Table 4) due probably to silvicultural practices (e.g. weeding and thinning) to promote the growth of planted individuals (Nagai and Yoshida 2006), dense establishment and rapid growth of a B. ermanii, a common pioneer tree species across the region (Umeki 2003; Yoshida et al. 2005), compensated the carbon accumulation. Naturally, the use of faster growing species for plantation would reduce the difference, but the advantage of natural regeneration is certainly dependable if we consider management costs.

Total carbon stocks 35 years after soil scarification, however, were similar to those in the untreated stands. Although we note this should be generalized carefully because we assumed the untreated stands are at a stable state, we suppose this is attributed to the reduction of carbon in the surface soil; only two thirds of the carbon stock was found in the oldest (about 35-year-old) scarified stands compared with the untreated dwarf bamboo stands (Fig. 2f), suggesting that carbon stock in soil could not be recovered in about 35 years after treatment. In fact, the untreated stands (UTsk and UTss) generally had soil with higher carbon concentrations than the corresponding treated stands (Table 3). As shown in previous studies, soil was the important carbon sink (Dixon et al. 1994; 
Schimel 1995; also see Fig 3), and the decline continued for a long period (Peichl and Arain 2006; Dawson and Smith 2007; Jandl et al. 2007). Intensive soil disturbances such as soil scarification, as well as cultivation (Song et al. 2005), can expose the ground to direct sunlight and increase soil temperature. The resultant high decomposition rate may limit the accumulation of organic matter during the age-sequences (Ozawa et al. 2001).

The carbon stock recovery, defined as the proportion of carbon stock in the oldest stand to that in the corresponding untreated stand, was lower in NRsk than in NRss. The difference seemed to be attributed to the extent of the initial carbon reduction in the soil. In NRsk the depressed carbon stock in the soil was accounted for $30-40 \%$ of total carbon (Fig. 2f). As NRsk stands are mainly distributed in higher altitude areas (Table 1), the possible lower temperature might delay the decomposition of organic matter. The removal of the soil with higher carbon concentration (Table 3) might cause the more drastic impact.

In general, carbon stock in woody debris increases significantly immediately after major disturbance (Hooker and Compton 2003; Rothstein et al. 2004). However, because of the absence of overstory trees in the untreated condition, the accumulation rates of the litter and woody debris were low (Fig 3), and the relation to stand age were not significant for NRsk and PLss in this study.

\section{Implications for management}

On the basis of our findings, the management practices should examine the balance between plant carbon accumulation and soil carbon reduction. In particular, we should put emphasis on soil, which was found to be the highest but most vulnerable carbon stock. We conclude that intensity of soil disturbance should be reduced as much as possible in the management. Although we need a further study to quantify the age-sequential change in untreated stands, a longer rotation period (i.e., at least 50 years) would be appropriate to ensure that the scarified stands become longer-term carbon sinks and begin to accumulate carbon at a greater rate than the untreated stands.

We can recommend that some portion of the stand should remain intact to maintain the surface 
soil (e.g. strip- or patch-scarification). Since the density of B. ermanii at the naturally regenerated stands was so high (Table 1), the density reduction caused by the untreated strips or patches would not severely reduce plant carbon accumulation in a later stage of development. Increasing the edge area around the stripes or patches would contribute to fast growth of some trees, which might compensate the carbon stock through increasing the mean individual tree size. Although we should concern about more rapid recovery of dwarf bamboos from the untreated stripes or patches, we can expect significant reduction of management costs through limiting the actual treatment area. In addition, because of its higher recovery, we considered that $S$. senanensis-dominated stands are more appropriate candidates for sink activity than S. kurilensis stands. This might also contribute to the recovery of natural vegetation, because regeneration in NRss contained a more diverse overstory component (Fig. 1), probably resulting from a more abundant seed source from surrounding natural forests (Yoshida et al. 2005; Resco de Dios et al. 2005).

Furthermore, we demonstrated the possibility of the soil-replace treatment (Aoyama et al. 2009) as an effective sink activity. Our results suggested that soil replacing accelerated the carbon stock rate by at least 10 years (Fig. 2g). Although the estimated high carbon stock in the belowground (Fig. 2c) should be discounted because it contained much dead roots, more rapid recovery in comparison with normal scarification treatment was obvious. It appeared that the treatment enhanced the growth of B. ermanii remarkably (Fig. 2d), through improving the hardness, moisture and nutrients of the substrate (Aoyama et al. 2009). However, as the density of the established B. ermanii was too high (9 stems/ $\mathrm{m}^{2}$ for 7-year-old INRss; Table 4) to expect vigorous growth of individuals, we should again consider the combination with introducing the stripe- or patch-treatment. We suspect that natural regeneration management using these improvements has the potential to be the most significant sink activity in forests in this region. Further studies are needed to evaluate the effect of these improved practices in the field in a long term. 


\section{Acknowledgements}

We would like to thank anonymous reviewers for their helpful comments and suggestions. Thanks are also extended to F. Satoh, and S. Uemura for their valuable comments, and members of the Uryu Experimental Forest for their assistance in the fieldwork. We thank the Biosphere Dynamics Research Group of the Institute of Low Temperature Science (especially K. Kujiraoka and A. Sumida), and the Teshio Experimental Forest (especially K. Takagi), Hokkaido University, for providing data applied to formulate the allometric equations. This study was partly supported by the research projects fund from the Ministry of Education, Culture, Sports, Science and Technology of Japan (No.14760095 and 17580123).

\section{References}

Aoyama K, Yoshida T, Kamitani T (2009) An alternative of soil scarification treatment for forest restoration: effects of soil replacement. J For Res 14:58-62

Caspersen JP, Pacala SW, Jenkins JC, Hurtt GC, Moorcroft PR, Birdsey RA (2000) Contributions of land-use history to carbon accumulation in U.S. forests. Science 5494:1148-1151

Coomes DA, Allen RB, Scott NA, Goulding C, Beets P (2002) Designing systems to monitor carbon stocks in forests and shrublands For Ecol Manage 164:89-108

Dawson JJC, Smith P (2007) Carbon losses from soil and its consequences for land-use management. Science of the Total Environment 382:165-190

Dixon RK, Brown S, Houghton RA, Solomon AM, Trexler MC, Wisniewski J (1994) Carbon pools and flux of global forest ecosystems. Science 263:185-190

Fukuzawa K, Shibata H, Takagi K, Satoh F, Koike T, Sasa K (2007) Vertical distribution and seasonal pattern of fine-root dynamics in a cool-temperate forest in northern Japan: implication of the understory vegetation, Sasa dwarf bamboo. Ecol Res 22:485-495

Gastaldello P, Ruel JC, Pare D (2007) Micro-variations in yellow birch (Betula alleghaniensis) 
growth conditions after patch scarification. For Ecol Manage 238:244-248

Haeussler S, Bartemucci P, Bedford L (2004) Succession and resilience in boreal mixedwood plant communities 15-16 years after silvicultural site preparation. For Ecol Manage 199:349-370

Hokkaido Prefecture (2009) A stastical table of forestry in Hokkaido 2008. Hokkaido Prefecture, Sapporo, Japan. (in Japanese*)

Hooker TD, Compton JE (2003) Forest ecosystem carbon and nitrogen accumulation during the first century after agricultural abandonment. Ecological Applications 13:299-313

Houghton RA, Hackler JL, Lawrence KT (1999) The U.S. carbon budget: Contributions from land-use change. Science 285:574-578

IGBP Terrestrial Carbon Working Group (1998) The terrestrial carbon cycle: Implications for the Kyoto Protocol. Science 280:1393

Jandl R, Lindner M, Vesterdal L, Bauwens B, Baritz R, Hagedorn F, Johnson DW, Minkkinen K, Byrne KA (2007) How strongly can forest management influence soil carbon sequestration? Geoderma 137:253-268

Jia S, Akiyama T (2005) A precise, unified method for estimating carbon stock in cool-temperate deciduous forest ecosystems. Agricultural and Forest Meteorology 134:70-80

Johnson DW, Curtis PS (2001) Effects of forest management on soil C and N stock: Meta analysis. For Ecol Manage 140:227-238

Kawahara T, Suzuki T (1981) Studies on Sasa communities (1) Biomass of Sasa kurilensis and Sasa senanensis communities. Journal of the Japanese Forestry Society 63:173-178

Laiho R, Prescott CE (1999) The contribution of coarse woody debris to carbon, nitrogen, and phosphorus cycles in three Rocky Mountain coniferous forests. Can J For Res 29: 1592-1603

Nagai M, Yoshida T (2006) Variation in understory structure and plant species diversity influenced by silvicultural treatments among 21-to 26-year-old Picea glehnii plantations. J For Res $11: 1-10$ 
Nilsson U, Gemmel P, Johansson U, Karlsson M, Welander T (2002) Natural regeneration of Norway spruce, scots pine and birch under Norway spruce shelterwoods of varying densities on a mesic-dry site in southern Sweden. For Ecol Manage 161:133-145

Noguchi M, Yoshida T (2004) Tree regeneration in partially cut conifer-hardwood mixed forests in northern Japan: Roles of establishment substrate and dwarf bamboo. For Ecol Manage 190:335-344

Noguchi M, Yoshida T (2005) Factors influencing the distribution of two co-occurring dwarf bamboo species (Sasa kurilensis and Sasa senanensis) in a conifer-broadleaved mixed stand in northern Hokkaido. Ecol Res 120:25-30

Ozawa M, Shibata H, Satoh F, Sasa K (2001) Effect of surface soil removal on dynamics of dissolved inorganic nitrogen in snow-dominated forest soil. The Scientific World 1:527-533

Peichl M, Arain MA (2006) Above- and belowground ecosystem biomass and carbon pools in an age-sequence of temperate pine plantation forests. Agricultural and Forest Meteorology $140: 51-63$

Potter C, Klooster S, Nemani R, Genovese V, Hiatt S, Fladeland MG Cross P (2006) Estimating carbon budgets for U.S. ecosystems. EOS 87:85-96

Resco de Dios V, Yoshida T, Iga Y (2005) Effects of topsoil removal by soil-scarification on regeneration dynamics of mixed forests in Hokkaido, Northern Japan. For Ecol Manage 215:138-148

Research Group on Forest Productivity (1960) Studies on the productivity of the Forest 1: Essential Needle Leaved Forests of Hokkaido, Kokusaku Pulp Co. Ltd, Tokyo

Richter DD, Markewitz D, Trumbore SE, Wells CG (1999) Rapid accumulation and turnover of soil carbon in a re-establishing forest. Nature 400:56-58

Rothstein DE, Yermakov Z, Buell AL (2004) Loss and recover of ecosystem carbon pools following stand-replacing wildfire in Michigan jack pine forests. Can J For Res 34:1908-1918 
Sakai Y, Takahashi M (1999) Underground biomass of Abies sachalinensis, Picea glehnii and Larix leptolepis. Transactions of the meeting in Hokkaido branch of the Japanese Forestry Society 47:96-98 (in Japanese*)

Schimel D (1995) Terrestrial ecosystems and the carbon cycle. Global Change Biol 1:77-91

Song G, Li L, Pan G, Zhang Q (2005) Topsoil organic carbon stock of China and its loss by cultivation. Biogeochemistry 74:7-62

Tremblay S, Perie C, Ouimet R (2006) Changes in organic carbon stock in a 50 year white spruce plantation chronosequence established on fallow land in Quebec. Can J For Res 36:2713-2723

Umeki K (2003) The regeneration of natural forests on Hokkaido, northern Japan: results of scarification and problems remaining to be solved. Journal of the Japanese Forestry Society 85:246-251 (in Japanese with English summary)

Wirth C, Schulze ED, Luhker B, Grigoriev S, Siry M, Hardes G, Ziegler W, Backor M, Bauer G, Vygodskaya NN (2002) Fire and site type effects on the long-term carbon and nitrogen balance in pristine Siberian Scots pine forests. Plant and Soil 242:41-63

Wood Technology and Wood Utilization Division (1982) Properties of the important Japanese woods. Table of the properties of woods (Research note). Bull Forest and Forest Products Res Inst 319:85-126 (in Japanese with English summary)

Wurtz TL, Zasada JC (2001) An alternative to clear-cutting in the boreal forest of Alaska: a 27-year study of regeneration after shelterwood harvesting. Can J For Res 31:999-1011

Yoshida T, Iga Y, Ozawa M, Noguchi M, Shibata H (2005) Factors influencing early vegetation establishment following soil scarification in a mixed forest in northern Japan. Can J For Res $35: 175-188$

Zaczek JJ (2002) Composition, diversity, and height of tree regeneration, 3 years after soil scarification in a mixed-oak shelterwood. For Ecol Manage 163:205-215

Zak DR, Grigal DF, Gleeson S, Tilman D (1990) Carbon and nitrogen cycling during old-field 
Aoyama et al., 21

succession: constrains on plant and microbial biomass. Biogeochemistry 11:111-129

* The title was tentatively translated in English by the author.

Figure captions:

Fig. 1. Composition of aboveground vegetation in each stand. The proportions of each component to total dry mass are shown. Stand ages (or species names for UT) are followed by dry mass (Mg ha ${ }^{-1}$ ) in parentheses.

Fig. 2. Age-sequential changes in carbon stocks in each component (a-f) and in total (g). The values of untreated stands were plotted on age 1 . The bars indicate standard deviation. $\mathrm{R}^{2}$ and P-values are based on the linear regression. Lines indicate the significant regressions for NRsk (solid line), NRss (broken line) and PLss (dashed line).

Fig. 3. The proportion of each component to total carbon stocks in each stand. Stand ages (or species names for UT) are followed by the total estimate $\left(\mathrm{Mg} \mathrm{C} \mathrm{ha}^{-1}\right)$ in parentheses. 
Table 1 A list of the study stands.

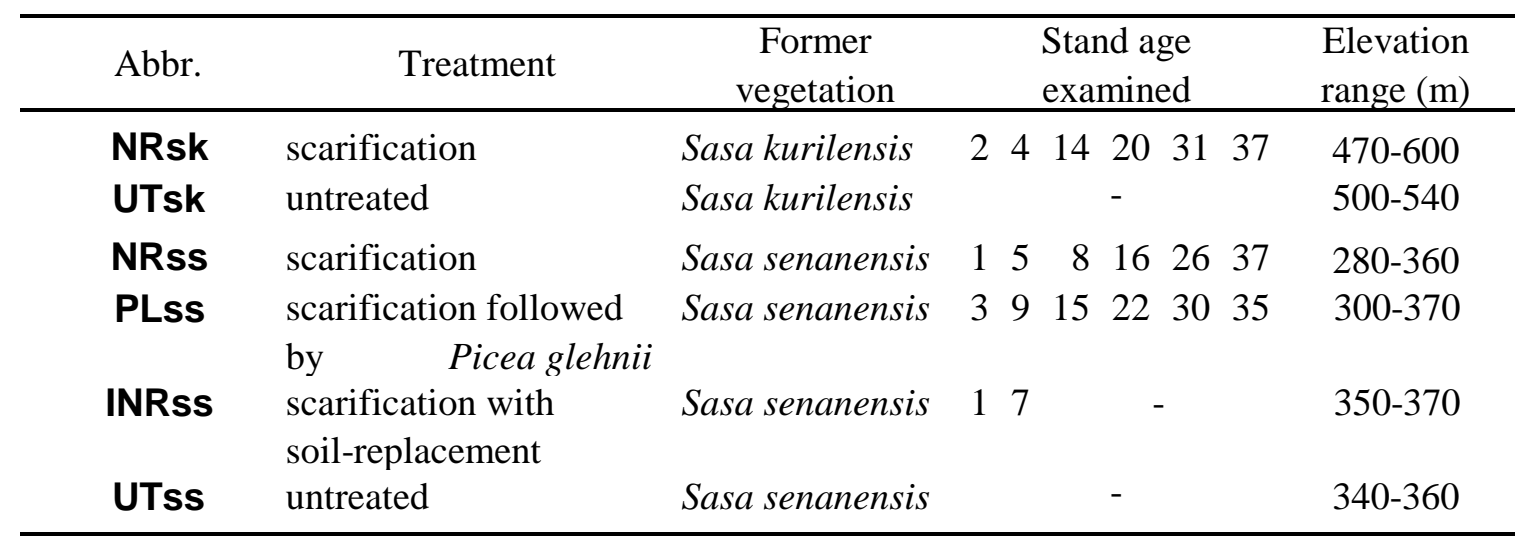

The stand age of PLss indicates the duration after the planting (not tree age). We assumed the untreated stands were representative of the pre-treatment condition. All the stands are located in flat area $\left(<3^{\circ}\right)$, with similar soil and bedrock conditions (see text for details). 
Table 2 Parameters of the allometric equations $\left(\mathrm{y}=a\left(\mathrm{DBH}^{2} \times\right.\right.$ $\mathrm{H})^{b}$ ) used to estimate biomass of overstory trees in this study.

\begin{tabular}{ccrcc}
\hline Classification & $\mathrm{y}$ & $a$ & $b$ & Reference \\
\hline Broadleaved & $\mathrm{W}_{\mathrm{S}}$ & 0.5325 & 0.9186 & 1 \\
(DBH equal or larger & $\mathrm{W}_{\mathrm{B}}$ & 0.0061 & 1.1927 & 1 \\
than 7.5cm) & $\mathrm{W}_{\mathrm{L}}$ & 0.1254 & 0.8019 & 1 \\
& $\mathrm{~W}_{\mathrm{R}}$ & 0.0535 & 1.0288 & 1 \\
\hline Broadleaved & $\mathrm{W}_{\mathrm{S}}$ & 0.6278 & 0.9004 & 1 \\
(DBH smaller than & $\mathrm{W}_{\mathrm{B}}$ & 0.0065 & 1.1859 & 1 \\
7.5cm) & $\mathrm{W}_{\mathrm{L}}$ & 0.0031 & 1.1885 & 1 \\
& $\mathrm{~W}_{\mathrm{R}}$ & 0.1257 & 0.9345 & 1 \\
\hline \multirow{2}{*}{ Conifer } & $\mathrm{W}_{\mathrm{S}}$ & 28.4700 & 0.9190 & $2^{*}$ \\
(DBH equal or larger & $\mathrm{W}_{\mathrm{B}}$ & 3.9380 & 0.9280 & $2^{*}$ \\
& $\mathrm{~W}_{\mathrm{L}}$ & 6.1170 & 0.8510 & $2 *$ \\
than 7.5cm) & $\mathrm{W}_{\mathrm{R}}$ & 0.0080 & 0.9240 & 3 \\
\hline & $\mathrm{W}_{\mathrm{S}}$ & 11.1240 & 0.6183 & 4 \\
Conifer & $\mathrm{W}_{\mathrm{B}}$ & 0.4202 & 0.8038 & 4 \\
(DBH smaller than & $\mathrm{W}_{\mathrm{L}}$ & 0.5409 & 0.8356 & 4 \\
7.5cm) & $\mathrm{W}_{\mathrm{R}}$ & 0.9562 & 0.8117 & 4 \\
\hline
\end{tabular}

$\mathrm{W}_{\mathrm{S}}$, stem; $\mathrm{W}_{\mathrm{B}}$, branch; $\mathrm{W}_{\mathrm{L}}$, leaf; $\mathrm{W}^{\mathrm{R}}$, root $(\mathrm{kg})$, $\mathrm{DBH}$, diameter at breast height $(\mathrm{cm}) ; \mathrm{H}$, height $(\mathrm{cm}) .{ }^{*}$, note the difference in the unit of $\mathrm{H}(\mathrm{m})$ from the other equations. 1, data for Betula ermanii presented by Kujiraoka et al. (in prep.), Teshio Experimental Forest (in prep.) and Uryu Experimental Forest (unpublished) were combined and used; 2, Research Group on Forest Productivity (1960) for Abies sachlinenis, Picea jezoensis, and P. glehnii ; 3 , Sakai and Takahashi (1999) for $P$. glehnii ; 4, Uryu Experimental Forest (unpublished) for $P$. glehnii. 
Table 3 The carbon concentrations determined from the samples of each

Plants

\begin{tabular}{lc}
\hline \multicolumn{1}{c}{ Component } & C (\%) \\
\hline tall forbs & 44 \\
tree saplings & 48 \\
dwarf bamboo & 45 \\
dwarf bamboo & 43 \\
other & 43 \\
understory & 44 \\
litter & 47 \\
\hline
\end{tabular}

\section{Soil}

\begin{tabular}{|c|c|c|c|c|}
\hline \multirow{2}{*}{$\begin{array}{c}\text { Stand } \\
\text { type }\end{array}$} & \multirow{2}{*}{$\begin{array}{c}\text { Stand } \\
\text { age }\end{array}$} & \multicolumn{3}{|c|}{ C (\%) } \\
\hline & & $0-0.1 \mathrm{~m}$ & $0-0.2 \mathrm{~m}$ & $0.2-0.3 \mathrm{~m}$ \\
\hline \multirow{6}{*}{ NRsk } & 2 & 7.3 & 3.8 & 4.0 \\
\hline & 4 & 5.1 & 7.7 & 6.7 \\
\hline & 14 & 8.7 & 3.6 & 3.6 \\
\hline & 20 & 2.5 & 10.0 & 8.2 \\
\hline & 31 & 6.9 & 7.3 & 5.2 \\
\hline & 37 & 5.0 & 10.1 & 8.0 \\
\hline Utsk & - & 13.3 & 11.9 & 8.7 \\
\hline \multirow{6}{*}{ NRss } & 1 & 3.6 & 3.2 & 2.9 \\
\hline & 5 & 8.3 & 6.2 & 3.8 \\
\hline & 8 & 4.9 & 2.6 & 1.9 \\
\hline & 16 & 4.0 & 2.1 & 1.7 \\
\hline & 26 & 5.5 & 4.5 & 3.2 \\
\hline & 34 & 6.1 & 5.9 & 2.5 \\
\hline \multirow{6}{*}{ PLss } & 3 & 3.6 & 3.9 & 3.6 \\
\hline & 9 & 4.9 & 6.7 & 6.0 \\
\hline & 15 & 4.0 & 4.3 & 3.6 \\
\hline & 22 & 5.5 & 4.2 & 3.4 \\
\hline & 30 & 6.1 & 5.3 & 4.1 \\
\hline & 35 & 6.1 & 6.3 & 4.8 \\
\hline \multirow{2}{*}{ INRss } & 1 & 4.0 & 4.2 & 3.3 \\
\hline & 7 & 5.4 & 6.3 & 4.7 \\
\hline Utss & - & 8.5 & 6.6 & 4.2 \\
\hline
\end{tabular}

Stand type is explained in Table 1. 
Table 4 Stem density (per $10 \mathrm{~m}^{2}$ ) of overstory trees (height equal or larger than $1.2 \mathrm{~m}$ ) in each DBH-class. The values in parentheses indicate the density of Betula spp. for NRsk, NRss and INRss, and the density of Picea glehnii for PLss.

\begin{tabular}{|c|c|c|c|c|c|c|c|c|}
\hline \multirow{2}{*}{$\begin{array}{c}\text { stand } \\
\text { type }\end{array}$} & \multirow{2}{*}{ Stand age } & \multicolumn{7}{|c|}{ DBH class $(\mathrm{cm})$} \\
\hline & & $0-5$ & 5-1 & & $10-$ & & 15 & \\
\hline \multirow{4}{*}{ NRsk } & 14 & 19.8 (18.6) & 0.2 & $(0.2)$ & 0.0 & $(0.0)$ & 0.0 & $(0.0)$ \\
\hline & 20 & $3.6 \quad(3.3)$ & 4.3 & (4.2) & 0.0 & $(0.0)$ & 0.0 & $(0.0)$ \\
\hline & 31 & $0.9 \quad(0.6)$ & 2.6 & (2.6) & 0.5 & (0.4) & 0.1 & (0.1) \\
\hline & 37 & $0.2 \quad(0.1)$ & 2.5 & (2.5) & 0.9 & (0.9) & 0.1 & (0.1) \\
\hline \multirow{5}{*}{ NRss } & 5 & $\begin{array}{ll}0.9 \quad(0.9) \\
\end{array}$ & 0.0 & $(0.0)$ & 0.0 & $\overline{(0.0)}$ & 0.0 & $\overline{(0.0)}$ \\
\hline & 8 & $6.9 \quad(6.5)$ & 0.0 & $(0.0)$ & 0.0 & $(0.0)$ & 0.0 & $(0.0)$ \\
\hline & 16 & $15.3(14.2)$ & 1.5 & (1.5) & 0.0 & $(0.0)$ & 0.0 & $(0.0)$ \\
\hline & 26 & $6.0 \quad(0.7)$ & 1.2 & (1.0) & 0.7 & (0.7) & 0.2 & $(0.2)$ \\
\hline & 34 & $0.7 \quad(0.5)$ & 1.0 & (0.7) & 0.6 & (0.4) & 0.4 & (0.4) \\
\hline \multirow{5}{*}{ PLss } & 9 & $0.9 \quad(0.8$ & 0.0 & $(0.0)$ & 0.0 & $(0.0)$ & 0.0 & $(0.0)$ \\
\hline & 15 & $27.5 \quad(2.1)$ & 0.2 & $(0.2)$ & 0.0 & $(0.0)$ & 0.0 & $(0.0)$ \\
\hline & 26 & $0.1 \quad(0.0)$ & 0.0 & $(0.0)$ & 0.1 & (0.1) & 0.8 & (0.8) \\
\hline & 30 & $0.9 \quad(0.0)$ & 0.0 & $(0.0)$ & 0.3 & (0.3) & 0.9 & (0.9) \\
\hline & 35 & $0.1 \quad(0.0)$ & 0.0 & $(0.0)$ & 0.5 & (0.3) & 0.8 & (0.8) \\
\hline INRsS & 7 & $90.4(87.2)$ & 0.0 & $(0.0)$ & 0.0 & $(0.0)$ & 0.0 & $(0.0)$ \\
\hline
\end{tabular}

Stand type is explained in Table 1 . The stands that are not appeared in this table did not contain overstory trees. 


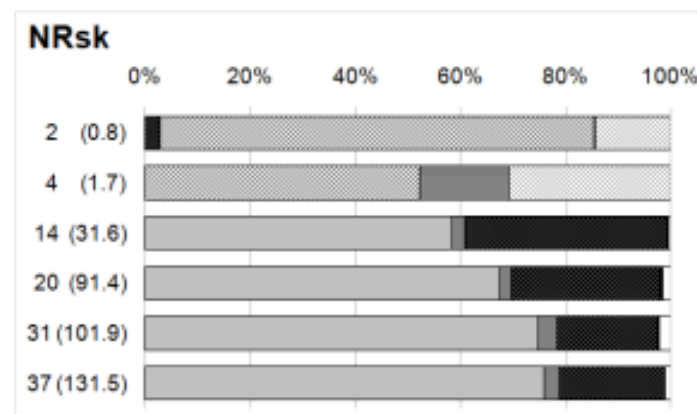

NRss

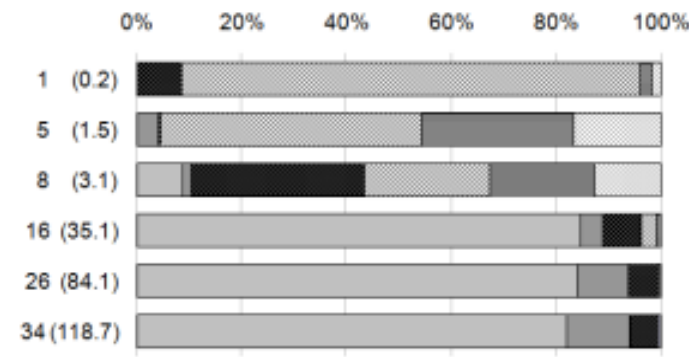

PLss

UT
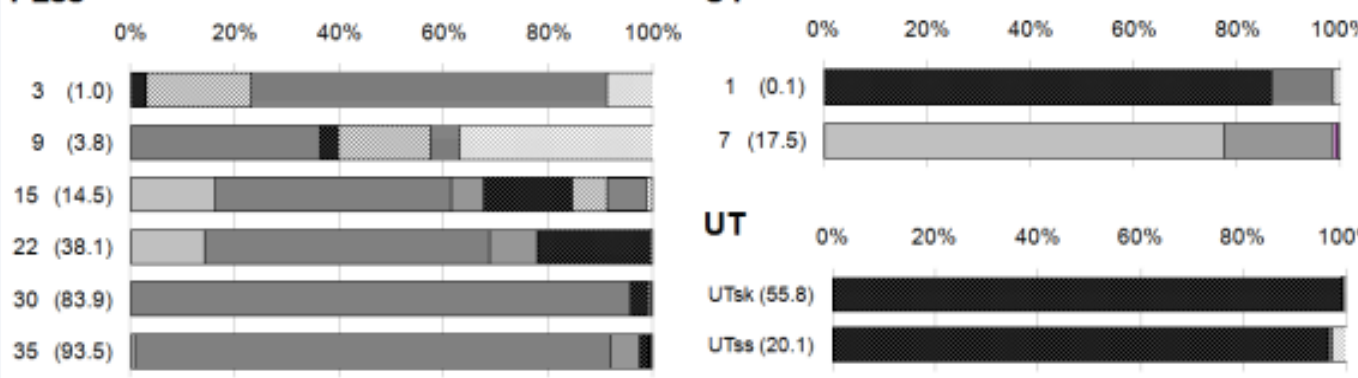

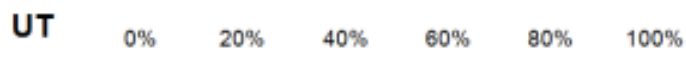

UTsk (55.8)

UTss (20.1)

$\begin{array}{llll}\text { 口Overstory (Betula) } & \text { a Overstory (Picea) } & \text { घOverstory (other sp.) } & \text { w Understory (dwarf bamboo) } \\ \text { aUnderstory (tall forbs) } & \text { aUnderstory (tree sapling) } & \text { aUnderstory (other sp.) } & \square \text { Standing dead }\end{array}$

Fig. 1. Composition of aboveground vegetation in each stand. The proportions of each component to total dry mass are shown. Stand ages (or species names for UT) are followed by dry mass $\left(\mathrm{Mg} \mathrm{ha}^{-1}\right)$ in parentheses. 

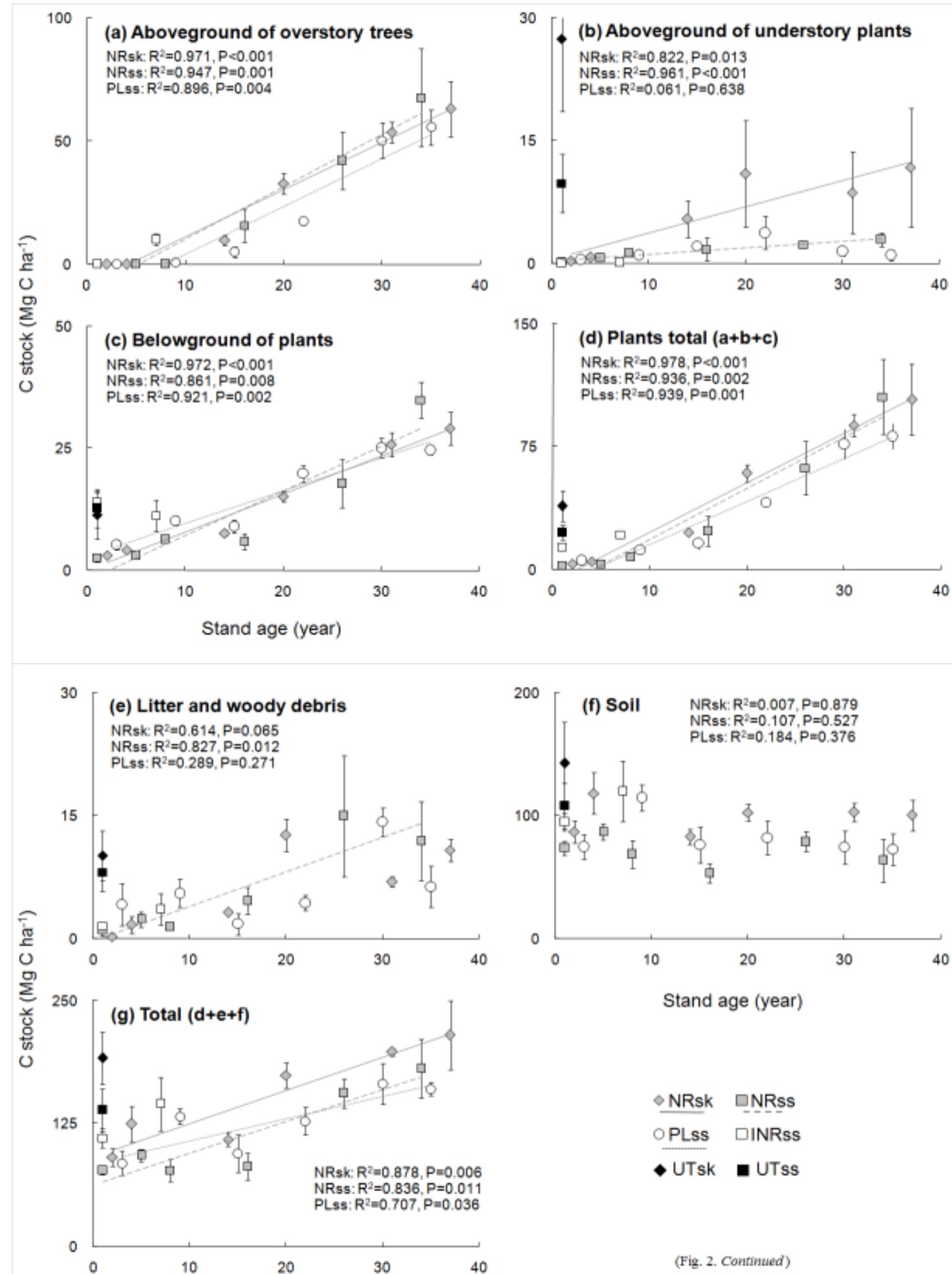

Fig. 2. Age-sequential changes in carbon stocks in each component (a-f) and in total (g). The values of untreated stands were plotted on age 1. The bars indicate standard deviation. R2 and P-values are based on the linear regression. Lines indicate the significant regressions for NRsk (solid line), NRss (broken line) and PLss (dashed line). 


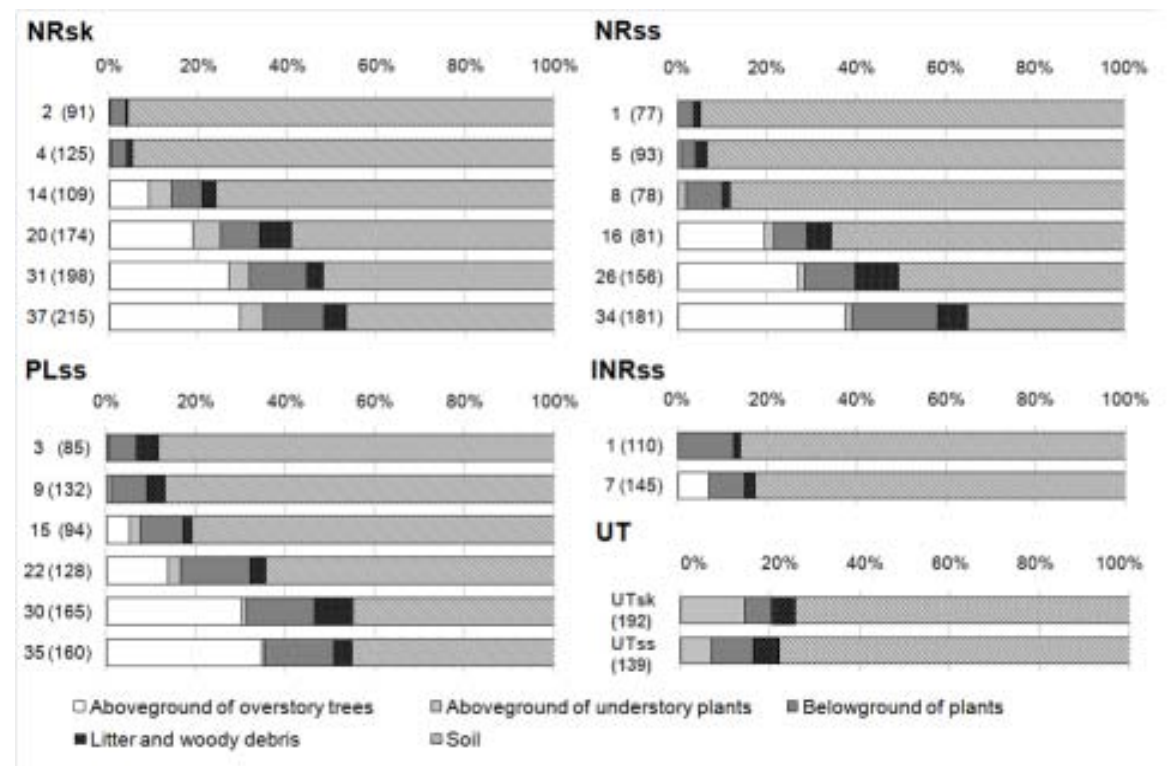

Fig. 3. The proportion of each component to total carbon stocks in each stand. Stand ages (or species names for UT) are followed by the total estimate (Mg C $\mathrm{ha}^{-1}$ ) in parentheses. 